\section{Original Research}

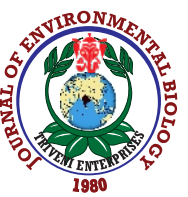

DOI : http://doi.org/10.22438/jeb/41/2(SI)/JEB-31

Journal Home page : www.jeb.co.in ^ E-mail : editor@jeb.co.in Journal of Environmental Biology

\title{
Investigation of old textiles using scanning electron microscopy
}

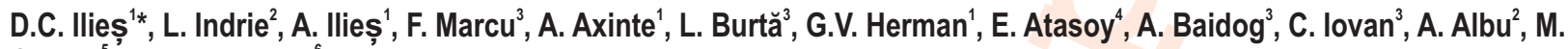 \\ Costea ${ }^{5}$ and J.A. Wendt \\ ${ }^{1}$ Faculty of Geography, Tourism and Sport, University of Oradea, Oradea - 410087, Romania \\ ${ }^{2}$ Department of Textile, Leather and Industrial Management, Faculty of Energy Engineering and Industrial Management, University of Oradea, \\ Oradea - 410058, Romania \\ ${ }^{3}$ Faculty of Medicine and Pharmacy, University of Oradea, Oradea - 410073, Romania \\ ${ }^{4}$ Department of Elementary Education, Faculty of Education, Uludag University, Gorukle/Bursa - 16059, Turkey \\ ${ }^{5}$ Faculty of Environmental Protection, University of Oradea, Oradea - 410048, Romania \\ ${ }^{6}$ Institute of Geography, Faculty of Oceanography and Geography, University of Gdansk, Gdańsk - 80309, Poland \\ *Corresponding Author Email : iliesdorina@yahoo.com
}

Abstract

Aim: The paper focus on some old textiles in Romania.

Methodology: Fungal contamination was determined using conventional techniques of open plates by Koch sedimentation method. Fibers and their (bio) deterioration phenomena was studied by scanning electron microscopy.

Results: Among the fungi identified on the investigated old textiles: Aspergillus sp., are common indoor and outdoor molds. It can cause problems in the conservation of cultural heritage and also pose risks to health and environment.

Interpretation: Monitoring of fungal contamination represents the basis for effective conservation strategy of indoor heritage environments.

Key words: Deterioration, Environment risks, Fibres, Old textiles

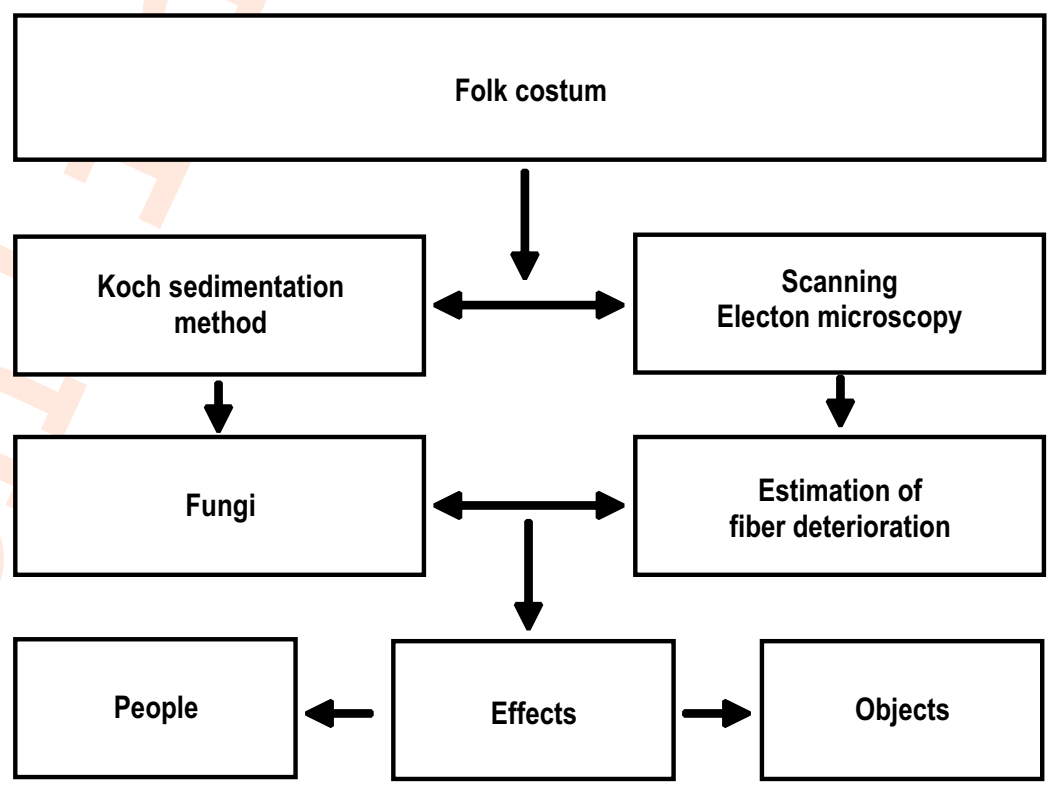

How to cite : Ilieș, D.C., L. Indrie, A. llieș, F. Marcu, A. Axinte, L. Burtă, G.V. Herman, E. Atasoy, A. Baidog, C. lovan, A. Albu, M. Costea and J.A. Wendt: Investigations of aged textiles using scanning electron microscopy. J. Environ. Biol., 41, 499-504 (2020). 


\section{Introduction}

Tangible cultural heritage, represented by aged textiles, stowed in storage facilities is exposed to physical, chemical and also microbiological environmental risk factors, may have negative consequences on integrity and cultural function (Rădulescu et al., 2018). Biodeteriogens are able to decompose the museum pieces. Fungal biodeterioration can contribute to aesthetical and structural damage of materials (Kavkler et al., 2015), the effect increases due to improper deposition because of natural (floods) and/or anthropic hazards (fire, insolation etc). Decomposition of plant residues/tissues and the resulting release of nutrient elements are key functions of soil microorganisms (Rottmann et al., 2010; Bargali et al., 1993, 2015). Bio-aerosols can harm museum curators and visitors' health.

SEM is one of the most versatile instrument for examining microstructural characteristics of solid objects (Goldstein et al., 1992). In addition, SEM is the most suitable technique for fibre analysis and one of the non-destructive methods to estimate the condition of some Coptic Egyptian textile objects (Abdel-Kareem et al., 2005). The importance and relevance of the SEM method combined with other methods of investigation, regarding deterioration of the fibres of aged textile due surrounding environment, historical conservation process and fungi growth have been highlighted in studies conducted by Karadag and Torgan (2016), Ahmed et al. (2017), Osman et al. (2017), Scharff and Jørgensen (2017), Elamin et al. (2018). Also, in Romania, studies on the degradation of textiles using SEM have been done by Săndulache et al. (2018) who have analysed a textile sample from a national heritage collection in order to establish its level of degradation. Furthermore, studies using SEM corroborated with other methods on textile samples from the Romanian patrimony were conducted in 2018 by Mitran et al. (2018). The study aimed at examining both the chemical and physical investigation fibrous composition as well as the level of degradation of the samples. The impact of the fungi on heritage textile was highlighted by Rădulescu et al. (2018). The present paper aims to investigate the internal structure and deterioration process of the fibres composing old textiles of folk costumes, which come into direct contact with the skin and pose secondary negative effects.

\section{Materials and Methods}

In this study an accelerated in-vitro biodeterioration test using some microfungi strains isolated form The National Museum for Romanian Peasant (Bucharest) on a textile material made of $100 \%$ wool fibres in order to show the accelerated biodegradation process due to the contamination with microfungi. In this case, SEM was used to analyse the modifications produced on the surface of the wool fibres.

To characterize the structure of fibres in depth and on the surface, Scanning Electron Microscopy (SEM) was carried out to capture high resolution images. For isolation of microorganisms on the fibres of folk costume, samples were taken from surfaces of approximately $1 \mathrm{~cm}^{2}$ with the help of sterile cotton swabs (Fernandes, 2006; llies' et al., 2018; Indrie et al., 2019). The decimal dilutions were performed; the cotton swabs were dipped in $1 \mathrm{ml}$ of sterile distilled water. Suitable dilutions of each sample were inoculated into nutrient agar on petri dishes to identify bacteria and on Sabouraud agar with chloramphenicol for isolation of fungi. The samples were incubated at $37^{\circ} \mathrm{C}$ for $72 \mathrm{hr}$. Bacteria were isolated and samples were subjected to a temperature of $25^{\circ} \mathrm{C}$ for 5-7 days in order to isolate the fungi. The morphological characteristics of fungal colonies were observed and identified according to Borrego et al. (2012).

\section{Results and Discussion}

Analysis of fibrous composition of the embroidered peasant shirt, ascertained that it was flax/linen. In the past, flax/linen, was the most used raw material in the peasant households. This plant was cultivated by the peasants in their own homestead. One of the reasons for using linen fabrics for traditional costumes high hygroscopicity of the fibre which can absorb moisture from the surrounding environment up to $30 \%$ of its own mass, thus providing. comfort to the body (Gribincea and Bordeianu, 2002). Analysing the SEM images of the fibres of peasant shirt (Fig. 1), it was found that it is a simple fibre linked structurally and functionally. further high fibre degradation was observed over the years due to the chemical composition $(80 \%$ cellulose content) of flax fibre and its structure (Preda and Preda, 1996). Oxygen and solar rays causes oxidative degradation of flax fibre. Also, depending on the relative humidity of the environment, the moisture content the strength and flexibility of these fibres over the years. Due to degradation of the fibres, the embroidered peasant shirt was both structural and colour, with oxidative yellowing over the years (Bordeianu, 2005). The microorganisms has first rottened the flax/linen and then disintegrated the fiber. Following the incubation of samples from the folk costumes, in this study Aspergillus was noted as a predominant fungal genera with known cellulytic activity (Fig. 2).

Influence on human health : Aspergillosis brings together all the diseases caused by Aspergillus in humans. Aspergillus is omnipresent in the environment, with multiple subtypes, species (over 200). Under certain favourable conditions, it becomes opportunistic, causing diseases. The risk of aspergillosis is mainly determined by the competence of immune system, the duration and frequency of exposure to Aspergillus spores. Generally, healthy body is able to neutralize the effects of spores in the body, the main risk factor is weak immune system, mainly in hematopoietic transplant patients, long-term neutropenia, solid organ transplantation, or immuno-suppressive therapy (Patterson et al., 2016). The most common Aspergillus species encountered in humans are $A$. fumigatus, $A$. niger, $A$. flavus, $A$. clavatus, $A$. versicolor. Aspergillus spores are small size, about 2-3 microns, 

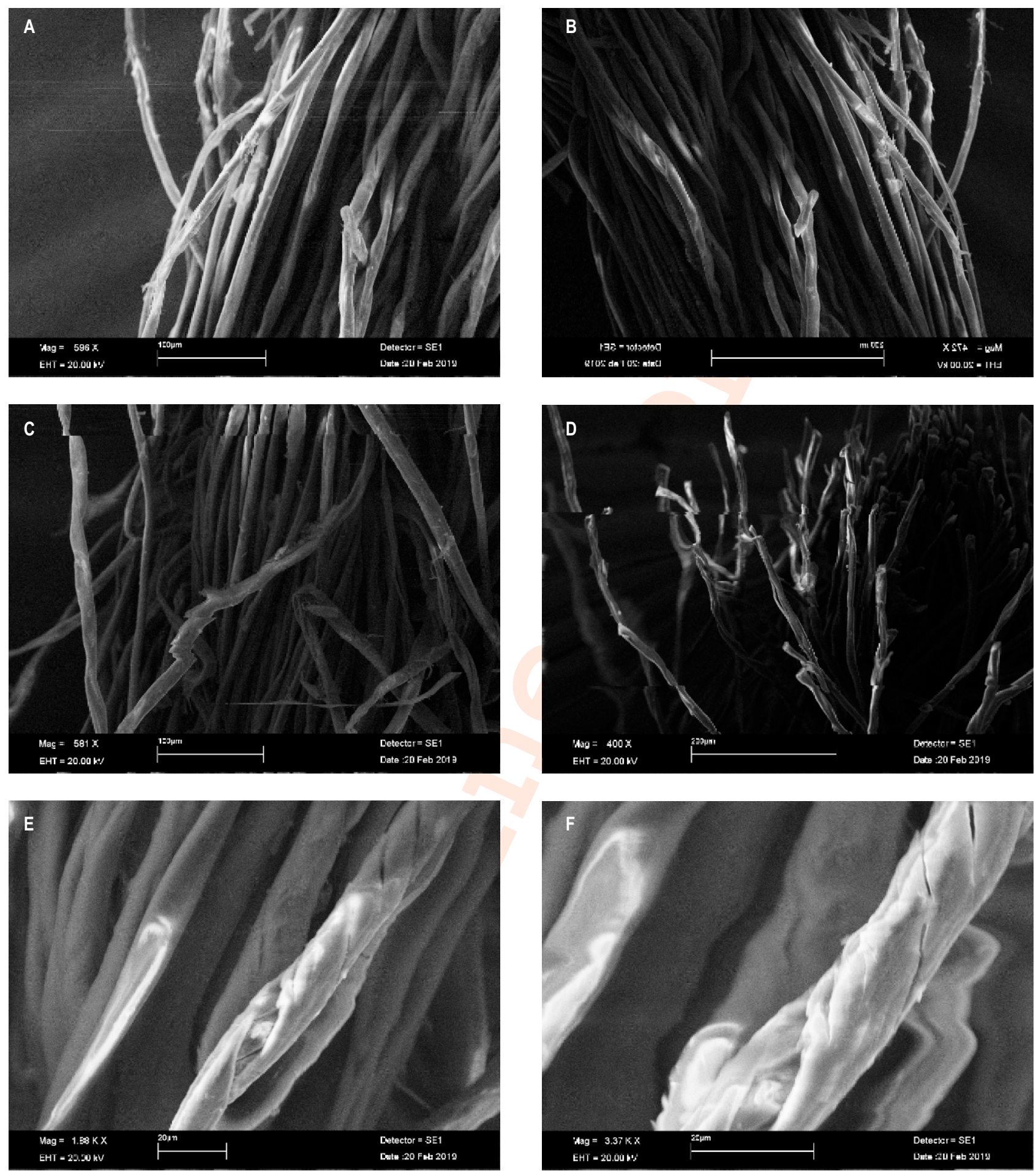

Fig. 1 : SEM images of aged fabric with different magnifications: (A) x596; (B) x574; (C) x581; (D) x400; (E) x1380 and (F) x 3370.

resistant to external environment, have the ability to penetrate the respiratory tract, up to the alveolar level, leading to colonization, multiplication and dissemination of fungi throughout the body, on haematogenous pathway. Thus, inhalation of fungal spores is the most frequent pathway (Panackal et al., 2010; llies et al., 2018).
Another way of infection is through expose skin, with extensive burns, vascular lesions of new-borns, etc. (Etienne et al., 2011), and also water contamination, rare but possible (Mesquita-Rocha et al., 2013). The main symptoms of aspergillosis are wheezing, fever, haemoptysis, cough and chest pain. 

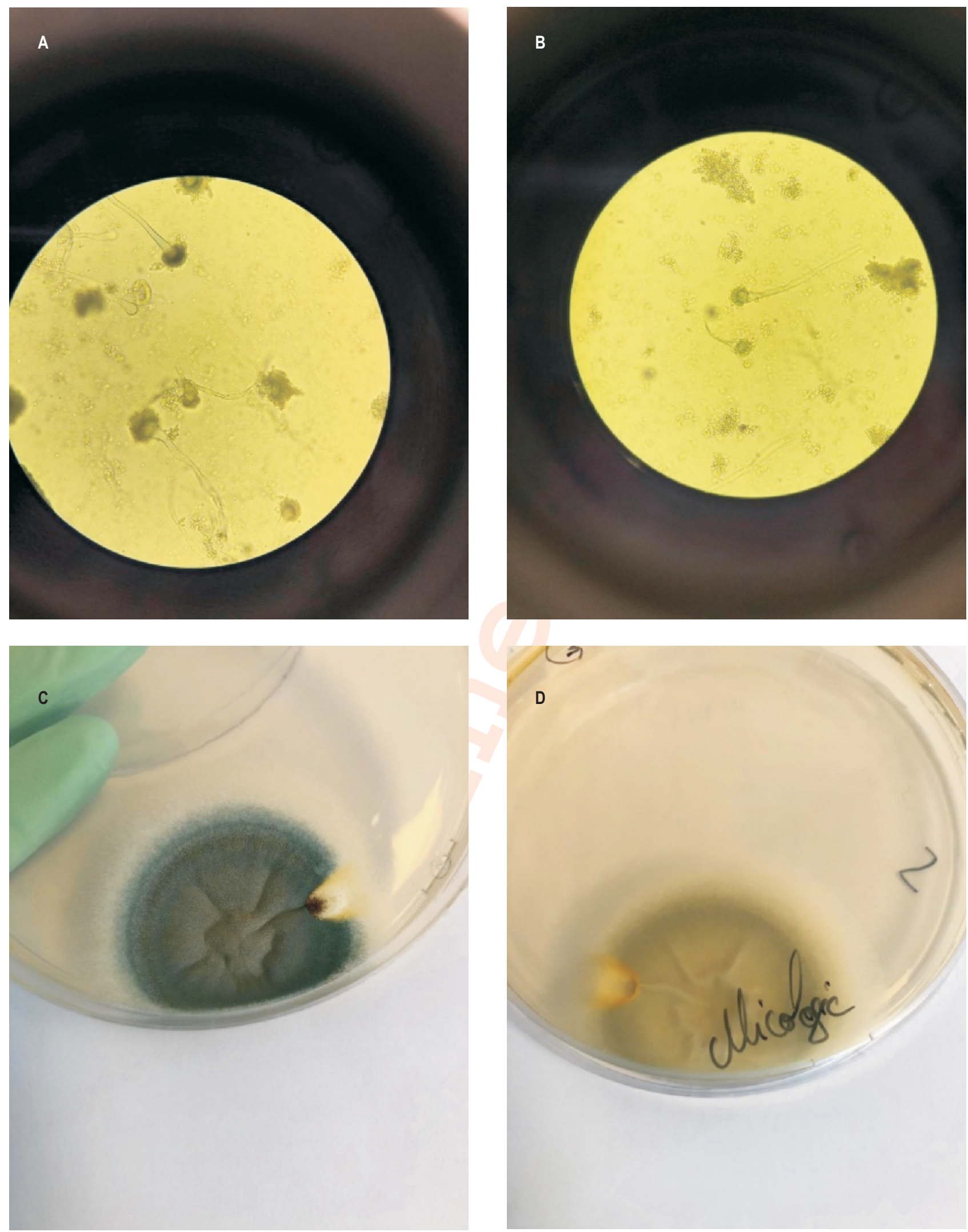

Fig. 2 : A-B: Determination of fungi- Aspergillus spp.; C-D: ultures of microfungi. 
There are mainly three major forms of Aspergillosis: Invasive Aspergillosis is the most severe and most important form with high mortality rate $(90 \%)$ where infection from pulmonary level is propagated by haematogenous to other organs (eye, central nervous system, sinuses, bones, etc.); Chronic I saprophytic aspergillosis, infeets varied localizations in the mucus tree or when there are chronic pulmonary diseases with pre-existing cavities (e.g. tuberculosis); Allergic aspergillosis is common in patients with asthma, bronchiectasis or cystic fibrosis. For certain diagnosis according to current guidelines, direct microscopic examination, culture and histopathological examination with pathogen identification are required (Ullmann et al., 2018). Currently, there is an intense concern regarding this affection because it is widespread, and is currently an important cause of mortality in immuno-weak patients. As treatment is complex, multidisciplinary, depending mainly on the location and type of infection, the emphasis is also on the prophylaxis of patients with high risk of fungal infections (Lackner et al., 2013; Heo etal., 2017).

For old textiles, the identification of fibres and their assessment is important. Scanning electron microscopy can help in studying deterioration of fibers. Microorganisms can cause problems in the conservation of cultural heritage due to their biodeteriorative potential and can pose risks to both health and environment. Therefore, monitoring fungal contamination should be the basis for making appropriate strategy for the management of museums, to protect critical heritage environments.

\section{Acknowledgments}

The research was possible by equal scientific involvement of all authors and acknowledge the support of the GrantPN-III-P1-1.2-PCCDI-2017-0686.

\section{References}

Abdel-Kareem, O. and K. El-Nagar: Non-destructive methods to investigate the deterioration extent of Coptic Egyptian Textiles. J. Tex.App., Technol. Manag., 4, 1-15(2005).

Ahmed, H., W. Mohamed, H. Saad, H. Nasr, M. Morsy and N. Mahmoud: Degradation behavior of nano-glue adhesive due to historical textiles conservation process. Egyp. J. Chem., 60, 1123-1133 (2017).

Bargali, S.S., S.P. Singh and R.P. Singh: Pattern of weight loss and nutrients release from decomposing leaf litter in age series of euclaypt plantations. Soil Biol. Biochem., 25, 1731-1738 (1993).

Bargali, S.S., K. Shukla, L. Singh, L. Ghosh and M.L. Lakhera: Leaf litter decomposition and nutrient dynamics in four tree species of dry deciduous forest. Trop. Ecol., 56, 57-66 (2015).

Bordeianu, L.: Fibre textile. Editura Universitatii din Oradea, Oradea (2005).

Borrego, S., P. Lavin, I. Perdomo, S. Gómez de Saravia and P. Guiamet: Determination of indoor air quality in archives and biodeterioration of the documentary heritage. ISRN Microbiology, Article ID $680598(2012)$
Elamin, A., K. Takatori, Y. Matsuda, M. Tsukada and F. Kirino: Microbiological, morphological and spectroscopic study on the effect of resinous materials in the preservation of wrapping textiles of mummies. Mediterranean Archaeol. Archae., 18, 1-10 (2018).

Etienne, K.A., C.P.K. Subudhi, P.R. Chadwick, P. Settle, J. Moise, S.S. Magill and S.A. Balajee: Investigation of a cluster of cutaneous aspergillosis in a neonatal intensive care unit. J. Hospi. Infect., 79, 344-348 (2011).

Fernandes, P.: Applied microbiology and biotechnology in the conservation of cultural heritage materials. Microbiol. Biotechnol., 73, 291-296 (2006).

Goldstein, J., D. Newbury, P. Echlin, D. Joy, A. Romig, C. Lyman, C. Fiori and E. Lifshin: Scanning electron microscopy and X-ray microanalysis. A text for biologists, materials scentists and geologists. Plenum Press, New York (1992).

Gribincea, V. and L. Bordeianu: Fibre textile-proprietati generale. Editura Performantica, lasi (2002).

Heo, S.T., A.M. Tatara, C. Jiménez-Ortigosa, Y. Jiang, R.E. Lewis, J. Tarrand and A.G. Mikos: Changes in in-vitro susceptibility patterns of Aspergillus to triazoles and correlation with aspergillosis outcome in a tertiary care cancer center, 1999-2015. Clini. Infect. Disea., 65, 216-225 (2017)

Ilies, D.C., A. Onet, J.A. Wendt, M. Ilieş, A. Timar, A. Ilies, S. Baias and G.V. Herman: Study on microbial and fungal contamination of air and wooden surfaces inside of a historical church from Romania. J. Environ. Biol., 39, 980-984 (2018).

Indrie, L., D. Oana, M. Ilieş, D.C. llieş, A. Lincu, A. Ilieş, Baias, G. Herman, A. Onet, M. Costea, F. Marcu, L. Burtă and I. Oana: Indoor air quality of museums and conservation of textiles art works. Case study: Salacea Museum House, Romania. Indust. Text., 70, 88-93 (2019).

Karadag, R. and E. Torgan: Advantages and importance of natural dyes in the restoration of textile cultural heritage. Int. J. Conser. Sci., 7, 357-366 (2016).

Kavkler, K., N.G. Cimerman, P. Zalar and A. Demšar: Fungal contamination of textile objects preserved in Slovene museums and religious institutions. Inter. Biodeteri. Biodegr., 97, 51-59 (2015).

Kersten, K.: Scanning Electron Microscopy (SEM): la tecnica più adatta per l'analisi delle fibre, http://www.microscopiaelettron icadabanco.it/tecnica-sem-analisi-fibre (2017).

Lackner, M. and C. Lass-Florl: Up-date on diagnostic strategies of invasive aspergillosis. Curr. Pharmaceutical Des., 19, 3595-3614 (2013).

Mesquita-Rocha, S., P.C. Godoy-Martinez, S.S. Gonçalves, M.D. Urrutia, F. Carlesse, A. Seber, M.A.A. Silvia, A.S. Petrilli and A.L. Colombo: The water supply system as a potential source of fungal infection in paediatric haematopoietic stem cell units. BMC Infec. disea., 13, 289 (2013).

Mitran E.C., G.L. Radu, E. Perdum, O.G. Iordache, I. Dumitrecu, A.A. Chivu and L.C. Miu: Characterization patrimony textile materials. Inter. Conf. Appl. Rese. Text., CIRAT-8 (2018).

Osman, E.M., Y.E. Zidan and N.K. Fahim: Determination of conservation state of Archaeological Moroccan Kilim by physical analytical methods. Int. J. Cons. Sci., 8, 51-58 (2017).

Panackal, A.A., H. Li, D.P. Kontoyiannis, M. Mori, C.A. Perego, M. Boeckh and K.A. Marr: Geoclimatic influences on invasive aspergillosis after hematopoietic stem cell transplantation. Clini. Infect. Disea., 50, 1588-1597 (2010). 
Patterson, T.F., G.R. Thompson III, D.W. Denning, J.A. Fishman, S. Hadley, R. Herbrecht and B.H. Segal: Practice guidelines for the diagnosis and management of aspergillosis: 2016 update by the Infectious Diseases Society of America. Clin. Infect. Disea., 63, e1e60 (2016).

Preda, C. and C. Preda: Metode şi aparate pentru controlul calităţii materialelor textile destinate confecţionării produselor de îmbrăcăminte. Editura BIT, Iaşi (1996).

Rădulescu, H., E. Perdum, C. Mitran, L. Dincă and V. Lazăr: Biodeteriogenic capacity of a microfungal species isolated from textile cultural heritage items on contemporary wool materials. The Publishing House of Romanian Academy, Series B, 20, 167-171 (2018).

Rottmann, N., J. Dyckmans and R.G. Joergensen: Microbial use and decomposition of maize leaf straw incubated in packed soil columns at different depths. Euro. J. Soil Biol., 46, 27-33 (2010).
Săndulache, I.M., E.C. Mitran, E. Perdum, O.G. lordache and A.M.A Chivu: Physical and chemical assessment of a patrimony sample. $7^{\text {th }}$ International Conference on Advanced Materials and Systems, ICAMS, pp. 469 - 473 (2018).

Scharff, A.B. and L.B. Jørgensen: Evaluating transmission electron microscopy as a method for assessing the condition of archaeological wool. In ICOM-CC $18^{\text {th }}$ Triennial Conference, pp. 1$8(2017)$

Ullmann A.J., J.M. Aguado, S.A. Akdagli, D.W. Denning, A.H. Groll, K. Lagrou and A. Warris: Diagnosis and management of Aspergillus diseases: Executive summary of the 2017 ESCMID-ECMM-ERS guideline. Clini. Microbiol. Infec., 24, e1-e38 (2018).

Wei, Q.F., X.Q. Wang, R.R. Mather and A.F. Fotheringham: New approaches to characterisation of textile materials using environmental scanning electron microscope. Fibr. Text. East. Eur., 12, 79-83 (2004). 